- For instance, in 1943, when a moreorganized approach to governmentsupported science was first being mooted in the United States, a Democratic Senator for West Virginia, Harvey Kilgore, proposed creating an office to "mobilize the scientific and technical resources of the nation". A correspondence in The New York Times warned that this suggestion for government-directed science represented "the latent germs of a form of communism that is most foreign to the ideals which our peoples are fighting to support". After the Second World War, engineer Vannevar Bush, who oversaw the seminal 1945 report Science - The Endless Frontier on US science policies, echoed Polanyi's thinking, arguing for public resources with little public accountability.

In the late 1940s, Bernal's career began to fade with his endorsement of the theory of agricultural genetics propounded by Russian agronomist Trofim Lysenko. This was elevated to Soviet policy, yet quickly discredited by scientists in the West. In 1948, Bernal debated against Polanyi on $\mathrm{BBC}$ radio, with Polanyi pointing to the suppression of science under Lysenkoism as evidence of the shortfalls of the state planning of science. The BBC's subsequent investigation revealed that nine Soviet geneticists had been put to death for expressing alternative views. Bernal's continuing defence of the theory, and his glowing 1953 obituary of Joseph Stalin in the magazine Modern Quarterly, contributed to his diminishing relevance.

Although Bernal lost the intellectual battle over cold-war politics, his ideas on the social function of science have triumphed on nearly every count. The larger and more significant effect of The Social Function of Science has been to anticipate and help the ideal of 'pure science' to reach mythical status, ushering in an era of science focused on societal needs, today characterized as 'grand challenges' by scientists and politicians.

Bernal, looking back at the book 25 years after its publication, emphasized that such needs implied more systematic thinking about science itself: "We need a strategy for research which must be based on a science of science." Today, whether it is a US senator, a British prime minister or a Chinese president expressing a view that science must serve society, each is reflecting Bernal's big idea. Seventy-five years on, that global influence on science-policy thinking is his classic's great legacy.

Roger Pielke Jr is director of the Center for Science and Technology Policy Research and professor of environmental studies at the University of Colorado Boulder. e-mail:pielke@colorado.edu

MICROBIOLOGY

Majority rule

Mark O. Martin relishes a stimulating tour of "little lives', from fungi to bacteria.

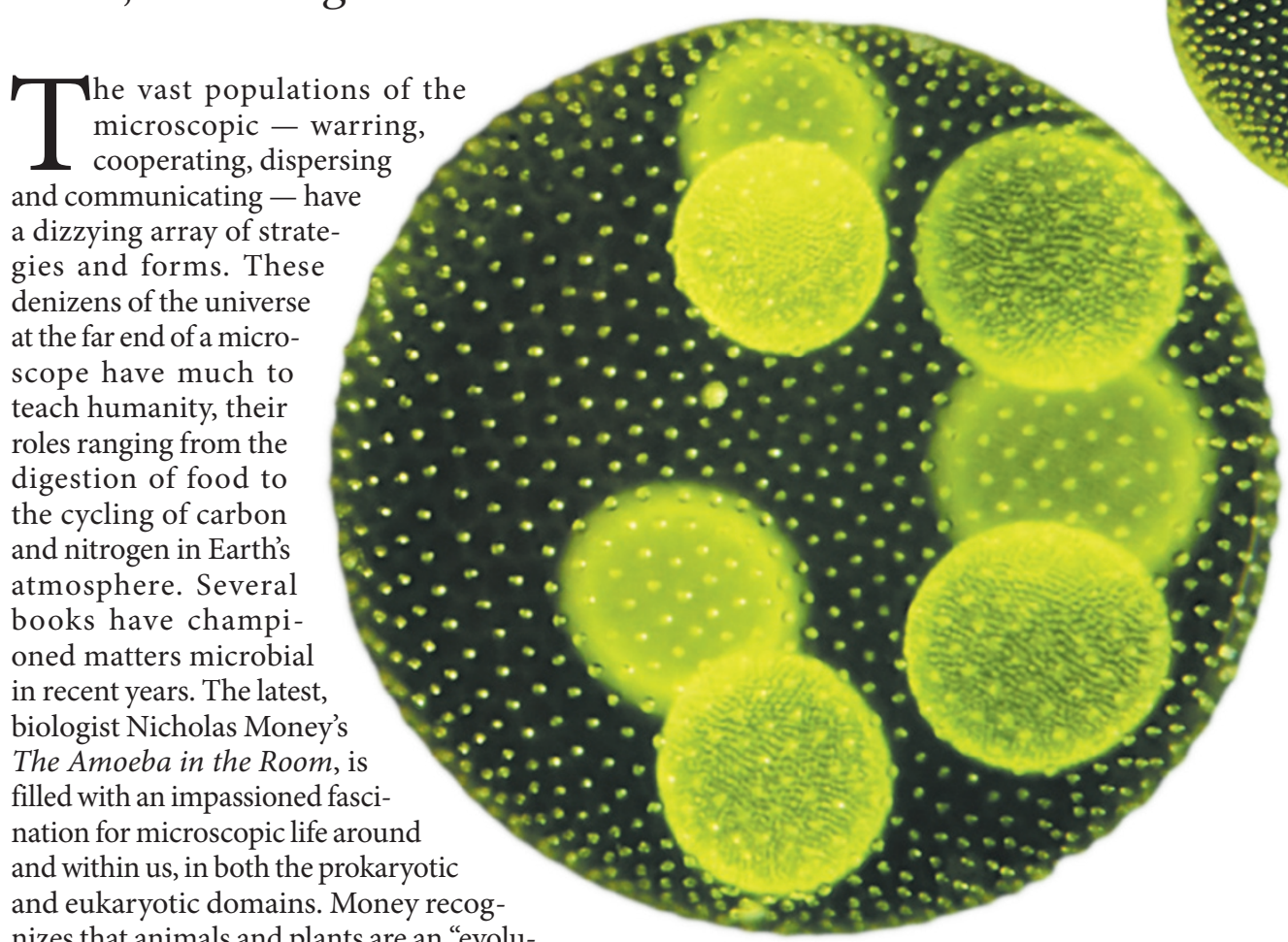
nizes that animals and plants are an "evolutionary afterthought" - as he writes, "the least part of life".

My interests tend toward the bacterial, viral and archaeal. Money covers this territory thoroughly, and goes beyond to sing the praises of fungi, algae and protists. Among others, he evocatively describes the water mould Haptoglossa, which uses microbial artillery to attack and consume nematode worms; Cryptomonas, a "Russian nesting doll" of an alga, evolved from four different organisms; and Polychaos dubium, a huge amoeba with perhaps the largest amount of DNA to be found in a nucleus. Overall, Money delivers a heady mixture of history, philosophy, art and even poetry: the chapters are prefaced with lines from John Milton's Paradise Lost.

Money begins with a 'macro' view of his garden pond, then dives into intricate details of the microbial populations in and around it. The seemingly uninhabited water swarms with communities as complex as any seen with the naked eye, and a

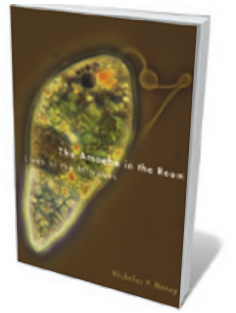

The Amoeba in the Room: Lives of the Microbes NICHOLAS P. MONEY Oxford University Press: 2014
Colonies of Volvox aureus algae, pregnant with daughter colonies.

tree branch is revealed as home to populations of interacting microbes. Money's point is that the diversity of life is clear enough on the macroscopic scale, but the organisma diversity of the microbial world is staggering. I particularly appreciated reading about the eight supergroups of microbial eukaryotes, including some familiar "animalcules" (such as the mitochondria-free pathogen Giardia, found among the Excavata).

A chapter on microscopy takes the reader from Assyrian craftsmen to familiar names such as seventeenth-century microbiological pioneers Robert Hooke and Antoni van Leeuwenhoek, as well as characters with whom I was not familiar. Bénédict Prévost, for instance, presented evidence that microbes can cause disease 50 years before Louis Pasteur, whereas Henry Baker popularized the use of microscopes to observe tiny wonders in 1742. We meet Ed Ricketts, US marine biologist and co-author of Between Pacific Tides (1939), as well as sculpture-like coccolithophores, numerous Prochlorococcus and ubiquitous marine bacteriophages. As in the rest of the book, Money enthusiastically presents evidence of diversity everywhere, no matter the magnification. 


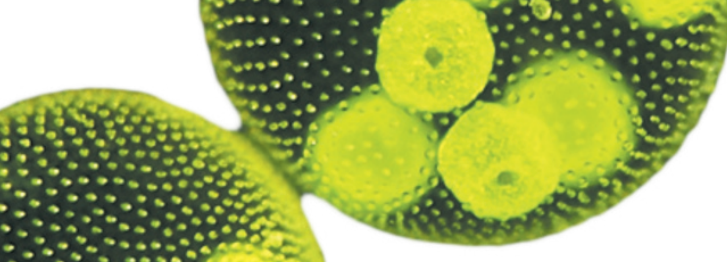

Money's tour of the air and its inhabitants reveals an intriguing experiment conducted by US aviator Charles Lindbergh, famous for making the first solo nonstop transatlantic flight in 1927. In the 1930s, the US Department of Agriculture asked Lindbergh and his wife, Anne, to gather air samples in a bid to understand the dispersal of cereal rusts. The two collected abundant rust spores using a plane fitted with a sky-hook, a device incorporating oiled microscope slides. Money also discusses how more recent researchers have speculated that some bacteria and microscopic algae control cloud formation and rainfall.

The co-evolution of human and microbe is amply explored. Those that cause disease or death - think pathogenic bacteria, flu viruses, malaria - have shaped our history. But, as researchers have discovered in the past century, the human body could not function without the estimated thousands of species of bacteria that inhabit our mouths, guts and other recesses. Like the pond and branch that Money probes early on, a human can be seen as a collection of ecological niches, albeit a mobile one.

\section{"Seemingly uninhabited} water swarms with communities and complex as any seen with the naked eye." Money goes on to discuss seemingly inhospitable environments (such as deep-sea hydrothermal vents, acidic areas or regions bombarded with high levels of radiation) in which microbes - such as archaeans that can grow at $121^{\circ} \mathrm{C}$ - prosper. He sums up with distressing prospects for extinctions and change, but also reassures: the microbial world is one of prodigious diversity, power and resilience.

This is a lucid and informative book. There is an impressive afterword of references and notes, and fine line drawings. So much that is lyrical and little-known waits to be discovered here - novelties that will appeal to new undergraduates as well as to incorrigible microbial enthusiasts like myself.

Mark O. Martin is associate professor of biology at the University of Puget Sound in Tacoma, Washington.

e-mail:momartin@pugetsound.edu

\section{Books in brief}

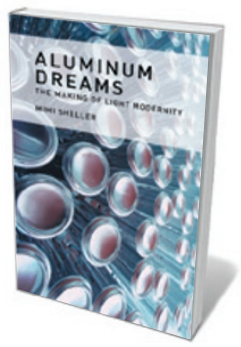

Aluminum Dreams: The Making of Light Modernity

Mimi Sheller MIT PRESS (2014)

It propelled humanity into air and space, transformed

communications and fed war machines. Aluminium — in aeroplanes, space capsules, satellites, bombs and baking foil — is welded into the built world. Mimi Sheller's coruscating cultural study reveals how young US chemist Charles Martin Hall and his French counterpart Paul Héroult simultaneously discovered the electrolytic production of aluminium in 1886; how designers were galvanized by its potential for the light and sleek; and how social and environmental problems from bauxite mining and aluminium smelting persist.

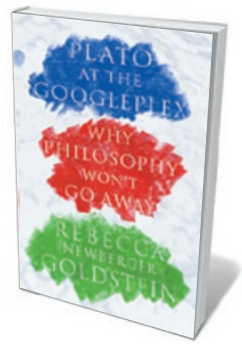

Plato at the Googleplex: Why Philosophy Won't Go Away

Rebecca Goldstein PANTHEON (2014)

Philosopher Rebecca Goldstein probes why Plato - and the philosophical enterprise itself — remains a force in science and culture 2,400 years on. Into a weighty discussion of the Platonic world view Goldstein inserts fictional interludes that see Plato, Chromebook in hand, touring the Googleplex, a neuroscience lab and beyond. Although contrived, this thought experiment usefully casts an eye on our turbocharged century. And it shows what survives of this classical titan: an ability to plumb the deep questions we still grapple with, from the nature of knowledge to morality.

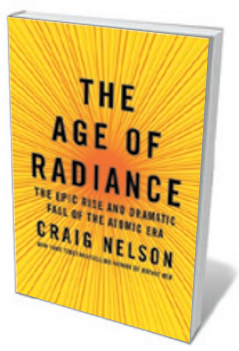

\section{The Age of Radiance: The Epic Rise and Dramatic Fall of the} Atomic Era

Craig Nelson SCRIBNER (2014)

Tomes on things atomic are rife - from discoveries by seminal physicists to meltdowns and crumbling nuclear arsenals. Craig Nelson braids the strands into a comprehensive chronicle that is also a wry elegy for an ebbing age. Starting with Wilhelm Röntgen's discovery of $X$-rays, Nelson gives us the panoply of physicists from Lise Meitner to Leo Szilard; offers a masterful reading of Hiroshima and Nagasaki; and takes us through weapons tests, the cold war, Fukushima, and the rest of our long attempt to "live with blessed curses".

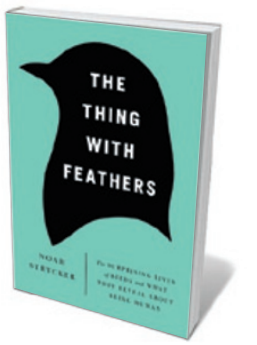

The Thing with Feathers: The Surprising Lives of Birds and What They Reveal About Being Human

Noah Strycker RIVERHEAD (2014)

Birds intrigue humanity, and in this research round-up Noah Strycker reveals why - in marvels such as the equal-radius flight paths of flocking starlings and the decontamination chamber that is a vulture's stomach. As he notes, such findings can mirror human realities. Clark's nutcrackers, for instance, can recall the location of 5,000 seed caches. Yet, in captivity some wild species lose substantial hippocampal volume (and memory) within weeks - an echo of the rapid losses found in patients with Alzheimer's disease.

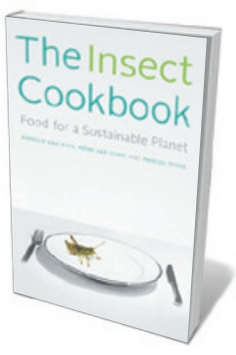

The Insect Cookbook: Food for a Sustainable Planet

Arnold van Huis, Henk van Gurp and Marcel Dicke COLUMBIA UNIVERSITY PRESS (2014)

The looming squeeze on food security is forcing some scientists to look at the abundance of protein under our feet: insects. Here entomologists Arnold van Huis and Marcel Dicke team up with chef Henk van Gurp for a pragmatic introduction to entomophagy, covering insect farming, nutrition and cuisine. Tarte tatin with chocolate-coated grasshoppers? With 2 billion of us already popping mealworms and more, this is a case of joining the crowd. Barbara Kiser 